\title{
Analisis Pengaruh NPF, FDR, BOPO, CAR, dan GCG terhadap Kinerja Keuangan Bank Umum Syariah di Indonesia Periode 2013-2017
}

\author{
Rima Cahya Suwarno dan Ahmad Mifdlol Muthohar \\ Institut Agama Islam Negeri Salatiga
}

\begin{abstract}
This study aims to determine the Influence of NPF, FDR, BOPO, CAR, and GCG on Financial Performance of Sharia Commercial Banks in Indonesia Period 2013-2017. This research use quantitative research method with population in this research is all sharia commercial bank in Indonesia period 2013-2017. The total sample is eight of sharia commercial banks, based on purposive sampling method. Data collection is done by library method from journals, articles or literatures that related to required data, and documentation method of annual report and GCG implementation report of sharia public bank in question as well as data from OJK website. The research method used is statistical descriptive test, descriptive test by analyzing GCG through GCG implementation report using content analysis method, classical assumption test, multiple regression test. The results showed that simultaneously NPF, FDR, BOPO, CAR, and GCG variables significantly influence the Financial Performance of Sharia Commercial Banks in Indonesia Period 2013-2017. While the partial variable of NPF has positive effect not significant to ROA, FDR variable has positive effect not significant to ROA, $B O P O$ variable has significant negative effect to ROA, CAR variable has positive effect not significant, and GCG variable has positive effect not significant to ROA of Sharia Commercial Bank in Indonesia 2013-2017 period.
\end{abstract}

Keywords: NPF, FDR, BOPO, CAR, GCG and ROA.

\section{A. PENDAHULUAN}

Semakin ketatnya persaingan antarbank syariah maupun dengan bank konvensional, bank syariah dituntut untuk memiliki kinerja yang baik, agar dapat bersaing dalam pasar perbankan nasional di Indonesia. Profitabilitas atau rentabilitas adalah salah satu fokus utama yang selalu diperhatikan dalam menjalankan suatu usaha, khususnya perbankan. Ini dikarenakan bank dalam melaksanakan kegiatan operasionalnya ingin memperoleh keuntungan yang maksimal (Sudarwantoro, 2009: 3). Maka dari itu, bank akan selalu mengoptimalkan kinerja keuangan bank tersebut. 
Pengelolaan bank yang semakin baik akan memberikan keuntungan yang dapat meningkatkan profitabilitas. Profitabilitas merupakan salah satu indikator untuk mengetahui kinerja bank. Kemampuan bank dalam meningkatkan profitabilitas dapat menunjukan kinerja keuangan bank yang baik. Sebaliknya, jika profitabilitas yang dicapai rendah, maka kurang maksimal kinerja bank tersebut dalam menghasilkan laba.

Profitabilitas merupakan indikator yang paling tepat untuk mengukur kinerja suatu bank (Suryani, 2011). Dengan diketahuinya kinerja bank yang baik maka tingkat kepercayaan masyarakat terhadap bank akan meningkat, dan sebaliknya, jika kinerja bank menurun maka tingkat kepercayaan masyarakat terhadap bank juga akan berkurang. Dalam penelitian ini profitabilitas akan diproksikan dengan menggunakan Return On Asset (ROA) sebagai ukuran kinerja bank, karena ROA digunakan oleh manajemen bank untuk mengukur kemampuannya dalam memperoleh keuntungan secara keseluruhan. Semakin besar ROA menunjukkan kinerja keuangan yang semakin baik.

Alasan dipilihnya Return On Asset (ROA) sebagai ukuran kinerja adalah karena ROA digunakan untuk mengukur kemampuan manajemen bank dalam memperoleh keuntungan secara keseluruhan. Sebagaimana disebutkan oleh Dendawijaya (2009: 118) menambahkan semakin besar ROA bank, semakin besar pula tingkat keuntungan yang dicapai bank tersebut dan semakin baik pula posisi bank tersebut dan segi penggunaan aset. Di bawah ini adalah table mengenai perbandingan ROA bank konvensional dan ROA bank syariah periode 2013 sampai 2017:

Tabel 1

Rasio Keuangan ROA Bank Umum Konvensional dan ROA Bank Umum Syariah (dalam persen)

\begin{tabular}{|c|c|c|c|c|c|}
\hline Rasio & 2013 & 2014 & 2015 & 2016 & 2017 \\
\hline ROA BUK & 3,08 & 2,85 & 2,32 & 2,23 & 2,45 \\
\hline ROA BUS & 2,00 & 0,41 & 0,49 & 0,63 & 0,63 \\
\hline
\end{tabular}

Sumber: www.ojk.go.id, 2018 
Pada tabel 1, data tahun 2013 hingga 2017 ROA Bank Umum Syariah (BUS) mengalami perubahan yang fluktuatif. ROA Bank Umum Syariah (BUS) cenderung menurun di tahun 2013 sebesar 2,00\% sedangkan pada tahun 2014 hanya sebesar $0,41 \%$, dan prosentase ROA juga belum memenuhi standar rasio yang ditetapkan oleh Bank Indonesia, menurut SE No. 6/ 73/ INTERN 24 Desember 2004 yaitu minimal 0,5\%. Keadaan yang sama juga terjadi di tahun 2015, meskipun naik sebesar 0,08 prosentase ROA pada tahun 2015 juga belum memenuhi standar rasio.

Dari tabel 1.2 rata-rata ROA Bank Umum Syariah (BUS) juga lebih rendah daripada ROA Bank Umum Konvensional (BUK). Ini menunjukkan bahwa kemampuan Bank Umum Syariah (BUS) dalam menghasilkan laba operasional dari penggunaan asetnya, masih jauh tertinggal dengan Bank Umum Konvensional (BUK).

Berdasarkan fenomena di atas, tingkat ROA Bank Umum Syariah (BUS) harus diberi perhatian lebih, karena tingkat ROA yang tinggi dapat merefleksikan pertumbuhan perbankan yang baik pula. Sebagaimana disebutkan oleh Wibowo danSyaichu(2013) menambahkan Semakin tinggi Return On Asset (ROA) suatu bank, semakin besar pula tingkat keuntungan yang dicapai bank tersebut dan semakin baik pula posisi bank tersebut dari segi penggunaan asset.

Faktor-faktor yang mempengaruhi profitabilitas bank diantaraya ialah faktor permodalan, likuiditas, kualitas aktiva, efisiensi operasional serta tata kelola perusahaan. Terdapat alat ukur yang dapat dijadikan pengukur dari faktor-faktor yang mempengaruhi profitabilitas, yaitu Non Performing Financing (NPF), Financing to Deposit Ratio (FDR), Biaya Operasional Pendapatan Operasional (BOPO), Capital Adequency Ratio (CAR), dan Good corporate Governance (GCG). Perkembangan rata-rata rasio keuangan pada perbankan syariah di Indonesia tahun 2013-2017 dapat dilihat dalam table 2 sebagai berikut : 
Tabel 2

PERKEMBANGAN RASIO CAR, ROA, BOPO, FDR DAN NPF

PERBANKAN SYARIAH

Periode 2013- 2017

\begin{tabular}{|c|c|c|c|c|c|c|}
\hline No. & Indikator & $\begin{array}{c}2013 \\
(\%)\end{array}$ & $\begin{array}{c}2014 \\
(\%)\end{array}$ & $\begin{array}{c}2015 \\
(\%)\end{array}$ & $\begin{array}{c}2016 \\
(\%)\end{array}$ & $\begin{array}{c}2017 \\
(\%)\end{array}$ \\
\hline 1. & CAR & 14,42 & 15,74 & 15,43 & 16,63 & 17,91 \\
\hline 2. & ROA & 2,00 & 0,41 & 0,49 & 0,63 & 0,63 \\
\hline 3. & BOPO & 78,21 & 96,67 & 97,01 & 96,22 & 94,91 \\
\hline 4. & FDR & 100,31 & 86,6 & 88,03 & 85,99 & 79,65 \\
\hline 5. & NPF & 2,62 & 4,95 & 4,84 & 4,68 & 4,77 \\
\hline
\end{tabular}

Sumber : www.ojk.go.id, Statistika Perbankan Syariah

Berdasarkan tabel 2 di atas, pada tahun 2014 ke 2015 rata-rata NPF Bank Umum Syariah (BUS) mengalami kenaikan. Sebagian besar dana operasional setiap bank umum diputarkan dalam pembiayaan yang diberikan. Hal tersebut menggambarkan bahwa pembiayaan adalah sumber pendapatan terbesar, namun sekaligus sumber risiko operasi bisnis perbankan yang terbesar yang berakibat pada pembiayaan bermasalah bahkan macet, yang akan mengganggu operasional dan likuiditas bank (Muhammad, 2005). Risiko penyaluran pembiayaan dapat diukur dengan rasio NPF. Semakin tinggi rasio ini menunjukan bahwa bank tersebut tidak profesional dalam pengelolaan pembiayaannya (Riyadi, 2006). Tingkat kesehatan pembiayaan (NPF) ikut mempengaruhi pencapaian laba bank sehingga dapat disimpulkan hubungan NPF dan ROA adalah negatif.

Hal ini juga bertentangan dengan hasil penelitian yang dilakukan olehRamadhan (2015), Rahmat (2012), Pratiwi (2011), Lemiyana dan Litriani (2016), Bahri dan Suhadak (2013) bahwa NPF berpengaruh negatif terhadap ROA. Beberapa penelitian tersebut berbanding terbalik dengan penelitian yang dilakukan oleh Zulifiah dan Susilo (2014), Fakhrudin dan Purwanti (2015), Diknawati (2014) dengan hasil penelitian yang menunjukan NPF berpengaruh positif terhadap ROA. Dengan adanya research gap dari penelitian sebelumnya, maka perlu dilakukan penelitian lanjutan pengaruh NPF terhadap profitabilitas. 
Berdasarkan tabel 2 di atas, Financing to Deposit Ratio (FDR) mengalami penurunan yang sangat tajam pada tahun 2014 yaitu sebesar 86,6 persen dari tahun sebelumnya tahun 2013 sebesar 100,31 persen, dan kembali mengalami penurunan pada tahun 2017 sebesar 79,65 persen. FDR menyatakan seberapa jauh kemampuan bank dalam membayar kembali penarikan dana yang dilakukan deposan dengan mengandalkan kredit yang diberikan sebagai sumber likuiditasnya. Dengan kata lain, seberapa jauh pemberian pembiayaan kepada nasabah kredit dapat mengimbangi kewajiban bank untuk segera memenuhi permintaan deposan yang ingin menarik kembali uangnya yang telah digunakan oleh bank untuk memberikan pembiayaan (Dendawijaya, 2009:116). Rasio ini untuk mengetahui kemampuan bank dalam membayar kembali kewajiban kepada para nasabah yang telah menanamkan dana dengan pembiayaan yang telah diberikan kepada para debiturnya.

Hal ini juga bertentangan dengan hasil penelitian yang dilakukan oleh Wahyuni (2016), Layaman dan Al-Nisa (2016), Muliawati dan Khoirrudin (2015), Armereo (2015), dan Astohar (2016) bahwa FDRberpengaruh negatif terhadap Return On Asset (ROA). Beberapa penelitian tersebut berbanding terbalik dengan penelitian yang dilakukan oleh Mukti (2016), dan Yusuf (2017) bahwa FDR berpengaruh positif terhadap Return On Asset (ROA). Dengan adanya research gap dari penelitian sebelumnya, maka perlu dilakukan penelitian lanjutan pengaruh FDR terhadap profitabilitas.

Berdasarkan tabel 2 di atas, BOPO mengalami kenaikan yang tajam pada tahun 2014 yaitu sebesar 96,67 persen dari tahun sebelumnya pada tahun 2013 sebesar 78,21 persen. BOPO merupakan proksi dari tingkat efisiensi. Rasio BOPO bertujuan untuk mengukur tingkat efisiensi dan kemampuan bank dalam melakukan kegiatan operasinya. Jika rasio ini rendah maka kinerja bank yang bersangkutan menunjukan tingkat efisiensi yang tinggi (Riyadi, 2006). Tingkat efisiensi bank dalam menjalankan operasinya, berpengaruh terhadap tingkat pendapatan yang dihasilkan oleh bank. Sehingga hubungan antara ROA dan BOPO adalah negatif. 
Hal ini bertentangan dengan hasil penelitian yang dilakukan olehNiode (2016), Sejati (2016), Kurniasih (2012), Ramantha dan Prasanjaya (2013), Hakim dan Rafsanjani (2016) berpengaruh negatif terhadap Return On Asset (ROA). Sementara Rendiana (2015), Yusuf (2017), Irmawati dan Lestari (2014) meneliti bahwa BOPO berpengaruh positif terhadap terhadap return on asset (ROA). Dengan adanya research gap dari penelitian sebelumnya, maka perlu dilakukan penelitian lanjutan pengaruh BOPO terhadap profitabilitas.

Pada tahun 2013 ke 2014 dan juga pada tahun 2016 ke 2017, sebagaimanaditunjukkan table 2, rata-rata CAR mengalami kenaikan, sedangkan rata-rata ROA mengalami penurunan. Fakta ini bersimpangan dengan teori yang menyatakan bahwa CAR berpengaruh positif terhadap ROA.

Capital adequacy ratio (CAR) adalah rasio yang berkaitan dengan faktor permodalan bank untuk mengukur kecukupan modal yang dimiliki bank untuk menanggung aktiva yang berisiko. Apabila modal yang dimiliki oleh bank tersebut mampu menanggung risiko-risiko yang tidak dapat dihindari, maka bank dapat mengelola seluruh kegiatannya secara efisien, sehingga kekayaan yang dimiliki bank diharapkan semakin meningkat dan begitu pula sebaliknya (Pramudhito, 2014). Maka dapat disimpulkan hubungan CAR dan ROA adalah positif. Semakin besar rasio CAR maka semakin baik ROA suatu bank.

Meskipun disisi lain, masih ada sejumlah indikator yang menunjukkan perbaikan. Hal ini juga menunjukkan ketidak konsisten pertumbuhan Return On Asset (ROA), Capital Adequacy Ratio (CAR), Financing to Deposit Ratio (FDR), Non Performing Financing (NPF) dan Biaya Operasional Pendapatan Operasional (BOPO) perbankan syariah, sehingga perlu diketahui faktorfaktor yang mempengaruhi indikator tersebut agar dapat diambil langkah yang tepat guna perbaikan kinerja untuk meningkatkan profitabilitas perbankan syariah dan perlu dilakukan penelitian selanjutnya. 
Selain rasio keuangan, terdapat faktor lain yang mempengaruhi profitabilitas perbankan syariah, yaitu tata kelola perusahaan atau Good Corporate Governance.Mengenai pengertian GCG dalam dunia perbankan di Indonesia, dalam ketentuan Pasal 1 angka 6 Peraturan Bank Indonesia No. 8/4/PBI/2006 Tentang Pelaksanaan good corporate governance Bagi Bank Umum. Disebutkan bahwa good corporate governance adalah tata kelola bank yang menerapkan prinsip-prisip keterbukaan (transparancy), akuntabilitas (accountability), pertanggungjawaban (responbility), independensi (independency), dan kewajaran (fairness).

Kelahiran Good Corporate Governace (GCG) pada bank syariah berawal dari dikeluarkannya Peraturan Bank Indonesia (PBI) yang menekankan perlunya penerapan GCG pada perbankan, yaitu PBI No. 8/4/PBI/2006 tentang Pelaksanaan GCG bagi Bank Umum. PBI ini juga berlaku bagi bank syariah yang artinya perbankan syariah juga diwajibkan menerapkan prinsip GCG dalam pengoperasian kegiatannya. Namun sejak tahun 2010, PBI No. 8/4/PBI/2006 sudah tidak berlaku lagi bagi bank syariah. Sebagai gantinya, telah dikeluarkan PBI No. 11/33/PBI/2009 tentang Pelaksanaan GCG bagi Bank Umum Syariah dan Unit Usaha Syariah. Penggantian ini disebabkan karena GCG yang akan diterapkan pada perbankan syariah harus sesuai dengan prinsip syariah. Pelaksanaan GCG yang memenuhi prinsip syariah yang dimaksudkan dalam PBI ini tercermin dengan adanya pelaksanaan tugas dan tanggung jawab dewan pengawas syariah dalam mengelola kegiatan perbankan syariah (Prasetyo dan Indradie, 2009).

Wacana good corporate governance telah banyak diteliti di berbagai negara. Namun, penelitian tentang pengungkapan good corporate governance pada perbankan syariah belum banyak dilakukan. Hal ini dikarenakan industri perbankan syariah masih sangat hijau dan belum memiliki permasalahan yang terlalu kompleks. Namun, agar perbankan syariah semakin memiliki daya tawar di dalam industri keuangan global, penulis merasa perlu adanya upaya lebih bagi perbankan syariah untuk meningkatkan kualitas pengungkapan 
good corporate governance dengan keunikan perbankan syariah yang harus patuh pada aturan syariah. Pendapat ini mendukung pernyataan Alamanda (2013) bahwa bank syariah harus memenuhi prinsip-prinsip syariah yang selanjutnya diikuti oleh mekanisme good corporate governance pada lembaga tersebut.

Penelitian ini menggunakan acuan syarat minimum pelaporan tata kelola perusahaan sesuai PBI Nomor 11/33/PBI/2009 untuk BUS. Penggunaan peraturan tersebut sebagai benchmark dinilai lebih sesuai dengan keadaan di Indonesia dan dianggap mampu mencerminkan tingkat informasi yang diharapkan regulator dibanding menggunakan standar yang lain (Adiono dan Sholihin, 2014). Laporan tahunan yang digunakan adalah laporan tahun 2013 sampai 2017. Adapun metode yang dipakai adalah metode content analysis.

Good corporate governance dapat mempengaruhi kinerja keuangan. Hal ini dibuktikan secara empiris oleh peneliti-peneliti terdahulu seperti penelitian yang dilakukan Prasojo (2015), Theresia (2013), Andriani dan Agustami (2016) menunjukkan bahwa Good Corporate Governance (GCG) memiliki pengaruh positif terhadap Return On Asset (ROA). Hal ini bertentangan dengan hasil penelitian yang dilakukan kemudian Lina (2013) mengenai pengaruh Good Corporate Governance terhadap kinerja keuangan yang diukur dengan Return On Asset (ROA), dari hasil penelitian tersebut menyatakan bahwa Good Corporate Governance (GCG) memiliki pengaruh negatif dan signifikan terhadap Return On Asset (ROA).

Berdasarkan uraian diatas kita dapat melihat bahwa masih terdapat perbedaan dalam hasil penelitian-penelitian yang sudah dilakukan, sehingga adanya penelitian baru sangat penting dilakukan untuk mengetahui jawaban yang sesuai atas permasalahan.

Tujuan dari penelitian ini adalah untukmengetahui pengaruh secarasimultanmaupunparsialmasing-masingdarivariabel NPF, FDR, BOPO, CAR dan GCG terhadap kinerja keuangan pada bank umum syariah. 


\section{B. PEMBAHASAN}

\section{Teori Sinyal (Signalling theory)TeoriKeagenan(Agency)}

Signalling theori menjelaskan mengapa perusahaan mempuyai dorongan untuk memberikan informasi laporan keuangan pada pihak eksternal. Dorongan perusahaan untuk memberikan informasi karena terdapat asimetri informasi antara perusahaan dan pihak luar karena perusahaan mengetahui lebih banyak mengenai perusahaan dan prospek yang akan datang daripada pihak luar (investor dan kreditor). Kurangnya informasi bagi pihak luar mengenai perusahaan meyebabkan mereka melindungi diri mereka dengan memberikan harga yang rendah untuk perusahaan. Perusahaan dapat meningkatkan nilai perusahaan dengan mengurangi informasi asimetri. Salah satu cara untuk mengurangi informasi asimetri adalah dengan memberikan sinyal pada pihak luar (Arifin,2005:11). Dalam hal ini teori sinyal diperlukan untuk menjelaskan pihak eksternal tentang laporan keuangan bank syariah, sebagaibentukpertanggungjawabanataskinerja yang telahdilakukanoleh bank syariah.

Selanjutnya permasalahan keagenan diatasi dengan melaksanakan corporate governance. Corporate governance dilatarbelakangi oleh teori keagenan (agency theory)yang menyatakan bahwa permasalahan agency muncul ketika kepengurusan suatu perusanaan terpisah dari kepemilikannya. Dewan komisaris dan direksi yang berperan sebagai agen dalam suatu perusahaan diberi kewenangan untuk mengurus jalannya perusahaan dan mengambil keputusan atas nama pemilik. Dengan kewenangan yang dimiliki maka manajer mempunyai kemungkinan untuk tidak bertindak yang terbaik bagi kepentingan pemilik karena adanya perbedaan kepentingan (conflict of interest). Dengan kata lain, manajemen mempunyai kepentingan yang berbeda dengan kepentingan pemilik (Riyanto, 2003).

\section{Kinerja Keuangan}

Menurut Dendawijaya (2009:20) sebagai lembaga yang penting dalam perekonomian, bank syariah membutuhkan adanya pengawasan kinerja 
keuangan yang baik oleh regulator perbankan. Indikator untuk menilai kinerja keuangan suatu bank adalah melihat tingkat profitabilitasnya.

Menurut yang ditinjau dari tingkat efisiensi dan efektivitas operasi perusahaan dalam memperoleh keuntungan. Menurut Hasibuan (2008: 100) mengemukakan bahwa profitabilitas bank adalah suatu kemampuan suatu bank untuk memperoleh keuuntungan yang dinyatakan dalam persentase. Profitabilitas pada dasarnya adalah laba (Rupiah) yang dinyatakan dalam (persen) profit.

Return on Asset (ROA) merupakan bagian dari rasio profitabilitas dalam menganalisa laporan keuangan atas laporan kinerja keuangan perusahaan. Dalam penentuan tingkat kesehatan suatu bank, Bank Indonesia lebih mementingkan penilaian besarnya ROA karena Bank Indonesia sebagai pembina dan pengawas perbankan lebih mengutamakan nilai profitabilitas suatu bank yang diukur dengan aset yang dananya sebagian besar berasal dari dana simpanan masyarakat (Dendawijaya, 2009: 118).

\section{Non Performing Financing (NPF)}

Non Performing Financing (NPF) merupakan rasio keuangan yang menunjukkan risiko pembiayaan yang dihadapi bank akibat pemberian pembiayaan dan investasi dana bank pada portofolio yang berbeda. Semakin kecil Non Performing Financing (NPF) maka semakin kecil pula risiko pembiyaan yang ditanggung pihak bank. Dengan demikian apabila suatu bank mempunyai Non Performing Financing (NPF) yang tinggi, menunjukkan bahwa bank tersebut tidak professional dalam mengelola pembiayaannya, sekaligus memberikan indikasi bahwa tingkat risiko atau pemberian pembiayaan pada bank tersebut cukup tinggi searah dengan tingginya Non Performing Financing (NPF) yang dihadapi bank (Riyadi, 2006: 61). 


\section{Financing to Deposit Ratio (FDR)}

Menurut Dendawijaya (2009 : 116) Financing to deposit ratio (FDR) adalah seberapa besar bank dalam membayar kembali penarikan dana yang dilakukan deposan dengan mengandalikan pembiayaan yang diberikan sebagai sumber likuidiitasinya. Rasio FDR dalam perbankan konvensional dikenal dengan sebutan Loan to Deposit Ratio (LDR) (Rivai, 2010). Hutagalung, dkk (2013) menjelaskan semakin tinggi LDR maka laba bank semakin meningkat (dengan asumsi bank tersebut mampu menyalurkan kreditnya dengan efektif), dengan meningkatnya laba bank, maka kinerja bank juga meningkat.

\section{Biaya Operasional Pendapatan Operasional (BOPO)}

Rasio BOPO sering disebut rasio efisiensi karena digunakan untuk mengukur kemampuan manajemen dalam mengendalikan biaya operasional terhadap pendapatan operasional. Setiap peningkatan biaya operasional akan berakibat pada berkurangnya laba sebelum pajak dan akhirnya akan menurunkan laba atau profitabilitas (ROA) bank yang bersangkutan (Dendawijaya, 2009: 121).

\section{Capital Adequacy Ratio (CAR)}

Menurut Dendawijaya (2009: 121) Capital Adequacy Ratio adalah rasio yang memperlihatkan seberapa jauh seluruh aktiva bank yang mengandung risiko (kredit, penyertaan, surat berharga, tagihan, pada bank lain) ikut dibiayai dari dana modal sendiri bank, disamping memperoleh dana-dana dari sumber-sumber di luar bank, seperti dana masyarakat, pinjaman (utang), dan lain-lain.

\section{Good Corporate Governance (GCG)}

Mengenai pengertian GCG dalam dunia perbankan di Indonesia, dalam ketentuan Pasal 1 angka 6 Peraturan Bank Indonesia No. 8/4/PBI/2006 Tentang Pelaksanaan good corporate governance Bagi Bank Umum. Disebutkan bahwa good corporate governance adalah tata kelola bank yang menerapkan prinsip-prisip keterbukaan (transparancy), 
akuntabilitas (accountability), pertanggungjawaban (responbility), independensi (independency), dan kewajaran (fairness).

\section{Kerangka Penelitian}

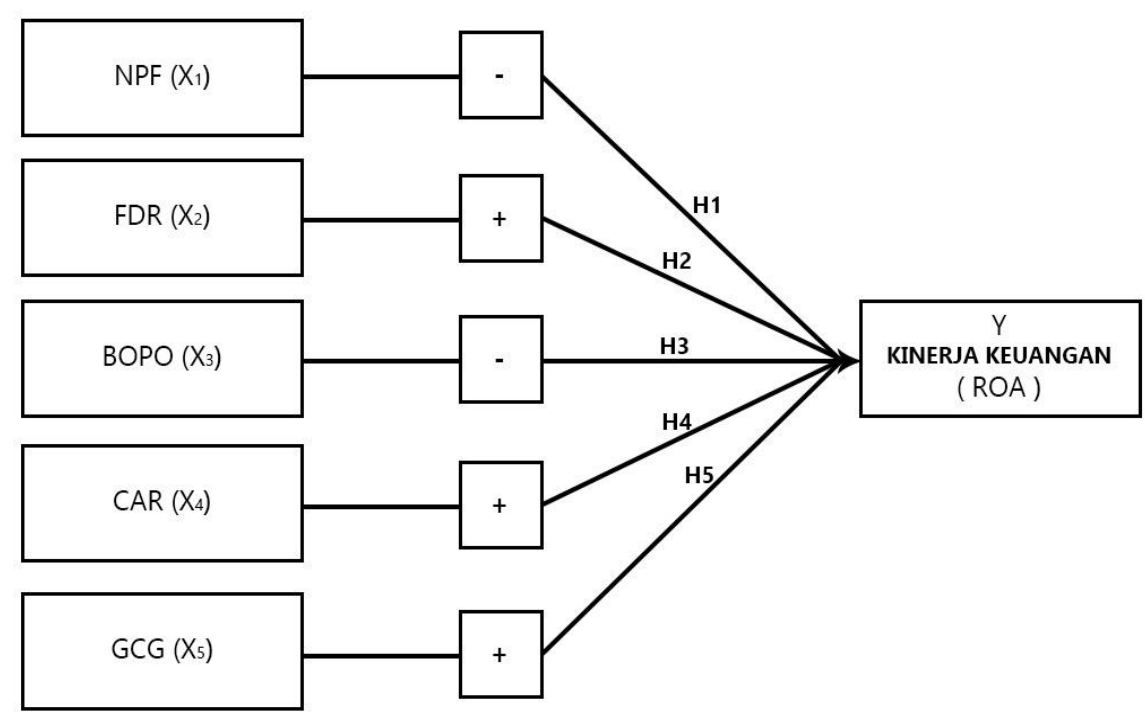

Gambar 1. Kerangka Penelitian

\section{Hipotesis}

H1. Non Performing Finance (NPF) berpengaruh negatif dan signifikan terhadap Kinerja Keuangan pada Bank Umum Syariah

H2. Financing to Deposit Ratio (FDR) berpengaruh positif dan signifikan terhadap Kinerja Keuangan pada Bank Umum Syariah.

H3. Biaya Operasional Pendapatan Operasional (BOPO) berpengaruh negatif dan signifikan terhadap Kinerja Keuangan pada Bank Umum Syariah.

H4. Capital Adequecy Ratio (CAR) berpengaruh positif dan signifikan terhadap Kinerja Keuangan pada Bank Umum Syariah.

H5. Good Corporate Governance (GCG) berpengaruh positif dan signifikan terhadap Kinerja Keuangan pada Bank Umum Syariah. 


\section{METODOLOGI PENELITIAN}

\section{JenisPenelitian}

Jenis penelitian yang digunakan dalam penelitian ini adalah penelitian kuantitatif. Penelitian kuantitatif adalah penelitian yang menekankan analisisnya pada data-data angka/numerikal (Azwar, 2014:126). Penelitian ini juga menjelaskan secara deskripif yaitu bertujuan untuk mendeskripsikan mengenai subyek dan obyek penelitian berdasarkan daya yang bersangkutan (Azwar, 2014 : 126).

\section{Populasi}

Populasi yang digunakan pada penelitian ini adalah 13 bank yang terdaftar sebagai bank umum syariah pada website Otsoritas Jasa Keuangan (OJK). Daftar populasi yang digunakan yaitu :

Tabel 3.1

\section{Daftar Populasi Penelitian}

\begin{tabular}{|l|l|}
\hline No. & \multicolumn{1}{|c|}{ Bank Umum Syariah } \\
\hline 1 & PT. Bank Aceh Syariah \\
\hline 2 & PT. Bank Muamalat Indonesia \\
\hline 3 & PT. Bank Victoria Syariah \\
\hline 4 & PT. Bank BRI Syariah \\
\hline 5. & PT. Bank Jabar Banten Syariah \\
\hline 6. & PT. Bank BNI Syariah \\
\hline 7. & PT. Bank Syariah Mandiri \\
\hline 8. & PT. Bank Mega Syariah \\
\hline 9. & PT. Bank Panin Syariah \\
\hline 10. & PT. Bank Syariah Bukopin \\
\hline 11. & PT. BCA Syariah \\
\hline 12. & PT. Maybank Syariah Indonesia \\
\hline 13. & PT. Bank Tabungan Pensiunan Nasional Syariah \\
\hline
\end{tabular}

Sumber: data yang diolah, 2018

\section{Sampel}

Metode penelitian ini menggunakan metode purposive sampling yaitu Pengambilan sampel yang berdasarkan atas suatu pertimbangan tertentu seperti sifat-sifat populasi ataupun ciri-ciri yang sudah diketahui sebelumnya (Notoadmodjo: 2010). Ciri - ciri pengambilan sampel yang digunakan adalah : 
a) Bank merupakan bank umum syariah di Indonesia yang telah memiliki annual report yang memuat data yang dibutuhkan.

b) Annual reportdan Laporan pelaksanaan GCGsudah dipublikasikan di website bank yang bersangkutan dan bisa diakses dari tahun 2013-2017.

Dari kriteria di atas, maka bank yang dijadikan sampel pada penelitian ini yaitu sebagai berikut :

Daftar Sampel Bank Umum Syariah

\begin{tabular}{|l|l|l|}
\hline No. & \multicolumn{1}{|c|}{ Bank Umum Syariah } & \multicolumn{1}{|c|}{ Kode Bank } \\
\hline 1. & PT. Bank Muamalat Indonesia & BMI \\
\hline 2. & PT. Bank Victoria Syariah & BVS \\
\hline 3. & PT. Bank BRI Syariah & BRIS \\
\hline 4. & PT. Bank BNI Syariah & BNIS \\
\hline 5. & PT. Bank Syariah Mandiri & BSM \\
\hline 6. & PT. Bank Mega Syariah & BMS \\
\hline 7. & PT. Bank Panin Syariah & BPS \\
\hline 8. & PT. BCA Syariah & BCAS \\
\hline
\end{tabular}

Sumber: data yang diolah, 2018

\section{Analisis Data}

\section{Uji Regresi Berganda}

Uji regresi ini digunakan untuk mengetahui pengaruh variabel independen terhadap variabel dependen.

\section{Hasil Uji Regresi}

\begin{tabular}{crrrr}
\hline \hline Variable & Coefficient & Std. Error & t-Statistic & Prob. \\
\hline \hline C & -0.035451 & 0.316278 & -0.112088 & 0.9120 \\
D(NPF,2) & 0.131970 & 0.276894 & 0.476608 & 0.6394 \\
D(FDR,2) & 0.069957 & 0.049968 & 1.400023 & 0.1785 \\
D(BOPO,2) & -0.072920 & 0.012531 & -5.819113 & 0.0000 \\
D(CAR,2) & 0.033306 & 0.078254 & 0.425615 & 0.6754 \\
D(GCG,2) & 0.006125 & 0.022799 & 0.268660 & 0.7912 \\
\hline \hline
\end{tabular}

Sumber : data yang diolah, 2018

Berdasarkan tabel 4.8, maka model regresi berganda antara variabel independen dan variabel dependen dapat dirumuskan dalam bentuk persamaan berikut : 


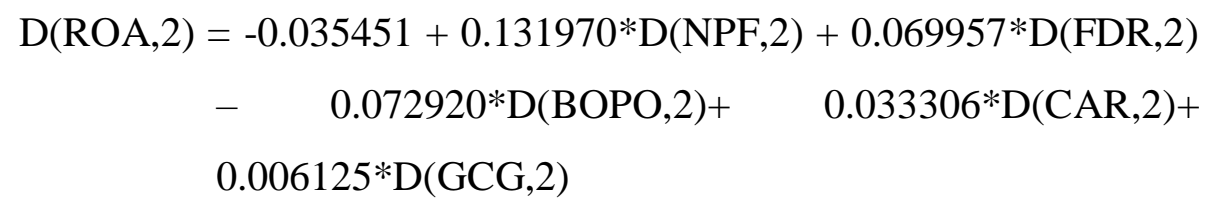

\section{a. $\mathbf{U j i} \mathbf{R}^{2}$ (Koefisien Determinasi)}

Koefisien Determinan digunakan untuk mengukur seberapa jauh kemampuan model dalam menerangkan variasi variaebel dependen.

\section{Tabel 4.9 Hasil Koefisien Determinasi}

\begin{tabular}{|r|r|r|}
\hline R Square & Adjusted R Square & Std. Error of the Estimate \\
\hline, 76480 &, 699492 & 1,391647 \\
\hline
\end{tabular}

a. Predictors: (Constant), GCG, FDR, BOPO, CAR, NPF

Sumber : data yang diolah,2018

Berdasarkan tabel 4.9 besarnya adjusted $\mathrm{R}^{2}$ adalah 0,699492 yang artinya 69,9\% kinerja keuangan (ROA) Bank Umum Syariah dipengaruhi oleh variabel independen, sedangkan 30,1\% dipengaruhi oleh faktor yang lain di luar penelitian.

\section{b. Uji Signifikansi Simultan (F-test)}

Uji Stastistik F digunakan untuk menunjukkan apakah semua variabel independen atau bebas yang dimaksutkan dalam model mempunyai pengaruh secara bersama-sama terhadap variabel dependen atau terikat.

\section{Tabel 4.10 Hasil Uji F}

\begin{tabular}{|l|r|}
\hline R-squared & 0.764820 \\
\hline Adjusted R-squared & 0.699492 \\
\hline S.E. of regression & 1.391647 \\
\hline Sum squared resid & 34.86028 \\
\hline Log likelihood & -38.53406 \\
\hline F-statistic & 11.70740 \\
\hline Prob(F-statistic) & 0.000038 \\
\hline \hline
\end{tabular}

Sumber : data yang diolah,2018 
Berdasarkan dari hasil uji F, diperoleh nilai F 11,707740 dan signifikasnis 0,000038 lebih kecil dari 0,05. Hal ini menunjukkan bahwa variabel NPF, FDR,BOPO, CAR, dan GCG secara simultan berpengaruh signifikansi terhadap kinerja keuangan (ROA) bank umum syariah di Indonesia periode tahun 2013-2017.

\section{c. Uji Signifikansi Parsial (Uji Statistik t)}

Uji statistik $\mathrm{t}$ digunakan untuk menunjukan apakah variabel independen atau bebas yang dimaksudkan dalam model mempunyai pengaruh secara individual terhadap variabel dependen atau terikat.

Tabel 3.Hasil Uji t

\begin{tabular}{crrrr}
\hline \hline Variable & Coefficient & Std. Error & t-Statistic & Prob. \\
\hline \hline C & -0.035451 & 0.316278 & -0.112088 & 0.9120 \\
D(NPF,2) & 0.131970 & 0.276894 & 0.476608 & 0.6394 \\
D(FDR,2) & 0.069957 & 0.049968 & 1.400023 & 0.1785 \\
D(BOPO,2) & -0.072920 & 0.012531 & -5.819113 & 0.0000 \\
D(CAR,2) & 0.033306 & 0.078254 & 0.425615 & 0.6754 \\
D(GCG,2) & 0.006125 & 0.022799 & 0.268660 & 0.7912 \\
\hline \hline
\end{tabular}

Sumber : data yang diolah, 2018

Berdasarkan tabel 4.11 di atas pengaruh variabel independen secara parsial adalah sebagai berikut :

\section{AnalisisPembahasan}

Variabel NPF bernilai positif pada t hitung 0,476608 dengan nilai signifikasi 0,6394. Karena nilai signifikasi 0,6394> 0,05 dan memiliki koefisien bernilai positif yaitu 0,6394, maka dapat disimpulkan bahwa hipotesis pertama (H1) ditolak artinya NPF berpengaruh positif tidak signifikan terhadap kinerja keuangan (ROA) bank umum syariah di Indonesia periode 2013-2017.

Berdasarkan nilai $t_{\text {hitung }}$ sebesar 0.476608 dan nilai itu lebih kecil daripada nilai $t_{\text {table }}$ sebesar 1,68967, sehingga dapat disimpulkan NPF berpengaruh positif tidak signifikan terhadap kinerja keuangan (ROA) bank umum syariah di Indonesia periode 2013-2017. Hasil 
penelitian ini sesuai pendapat Dewi (2017), Wibowo dan Syaichu (2013) yang menyatakan kondisi NPF yang lebih besar dalam satu periode tidak secara langsung memberikan penurunan laba pada periode yang sama. Hal ini dikarenakan pengaruh signifikan dari NPF terhadap ROA adalah berkaitan dengan penentuan tingkat kemacetan pembiayaan yang diberikan oleh sebuah bank. Di sisi lain adanya NPF yang tinggi akan dapat menggangu perputaran modal kerja dari bank. Maka manakala bank memiliki jumlah pembiayaan yang macet yang tinggi, maka bank akan berusaha terlebih dahulu mengevaluasi kinerja mereka dengan sementara menghentikan penyaluran pembiayaannya hingga NPF berkurang. Dan juga rata-rata NPF bank syariah di Indonesiamasih rendah dan dibawah angka standar BI yaitu sebesar 5\%, sehingga NPF bank Syariah tidak berpengaruh signifikan terhadap kinerja keuangan (ROA).

Penelitian ini didukung oleh Muliawati dan Khoiruddin (2015) yang menyatakan bahwa NPF berpengaruh positif tidak signifikan terhadap kinerja keuangan (ROA). Dikuatkan dengan argumentasi bahwa kondisi NPF yang lebih besar dalam satu periode tidak secara langsung memberikan penurunan laba pada periode yang sama. Hal ini dikarenakan pengaruh yang signifikan dari NPF terhadap ROA adalah berkaitan dengan penentuan tingkat kemacetan pembiayaan yang diberikan oleh sebuah bank. Hal ini karena pembiayaan merupakan sumber utama pendapatan bank (Muliawati dan Khoiruddin, 2015: 47).

Variabel FDR bernilai positif pada $t_{\text {hitung }} 1,40002$ dengan nilai signifikasi 0,1785. Karena nilai signifikasi 0,1785 > 0,05 dan memiliki koefisien bernilai positif yaitu 0,0669957, maka dapat disimpulkan bahwa hipotesis pertama (H1) ditolak artinya FDR berpengaruh positif tidak signifikan terhadap kinerja keuangan (ROA) bank umum syariah di Indonesia periode 2013-2017.

Berdasarkan nilai $t_{\text {hitung }}$ sebesar 1,40002dan nilai itu lebih kecil daripada nilai $t_{\text {table }}$ sebesar 1,68967, sehingga dapat disimpulkan FDR 
berpengaruh positif tidak signifikan terhadap kinerja keuangan (ROA). Hasil penelitian ini sesuai pendapat Sumarlin (2016) yang menyatakan tingginya pembiayaan yang diberikan perbankan tidak memberikan jaminan akan tingginya keuntungan yang diperoleh bank akibat adanya pembiayaan macet serta pembiayaan yang diberikan tidak dikelola dengan baik.

Penelitian ini didukung oleh Adyani dan Sampurno (2011), Sholihah dan Sriyana (2015) yang menyatakan bahwa FDR berpengaruh positif tidak signifikan terhadap kinerja keuangan (ROA). Hal ini disebakna besarnya rasio FDR diupayakan pada posisi $85 \%$ $100 \%$ agar dana yang disimpan dapat disalurkan dengan optimal. Oleh karena itu, pembiayaan yang relatif besar juga harus memperhatikan tingkat pengembalian pengelola modal. Sehinnga FDR yang relatif besar belum tentu dibarengi dengan ROA yang besar pula.

Variabel BOPO bernilai negatif pada $t_{\text {hitung }}-5,819113$ dengan nilai signifikasi 0,0000 . Karena nilai signifikasi $0,0000<0,05$ dan memiliki koefisien bernilai negatif yaitu -0,072920, maka dapat disimpulkan bahwa hipotesis ketiga (H3) diterima artinya BOPO berpengaruh negatif signifikan terhadap kinerja keuangan (ROA) bank umum syariah di Indonesia 2013-2017.

BOPO berpengaruh negatif signifikan terhadap kinerja keuangan (ROA). Hasil penelitian ini sesuai pendapat Nurvarida (2017) yang menyatakan Hubungan negatif antara BOPO dan ROA dapat diartikan bahwa semakin tinggi tingkat BOPO maka semakin rendah tingkat ROA suatu bank. Rendahnya tingkat BOPO menunjukkan kemampuan manajemen bank yang baik, dalam memenuhi biaya-biaya operasional dengan menghasilkan laba yang optimal. Sehingga berdampak pada ROA menjadi lebih baik.

Variabel CAR bernilai positif pada $t_{\text {hitung }} 0,425615$ dengan nilai signifikasi 0,6754. Karena nilai signifikasi 0,6754 > 0,05 dan memiliki koefisien bernilai positif yaitu 0,033306, maka dapat disimpulkan 
bahwa hipotesis pertama (H4) ditolak artinya CAR berpengaruh positif tidak signifikan terhadap kinerja keuangan (ROA). Ini berarti bahwa semakin tinggi tingkat kecukupan pemenuhan modal (CAR) suatu bank tidak menjadi tolak ukur keberhasilan manajemen bank dalam memperoleh untung yang tinggi

Berdasarkan nilai $t_{\text {hitung }}$ sebesar 1,40002dan nilai itu lebih kecil daripada nilai $t_{\text {table }}$ sebesar 1,68967, sehingga dapat disimpulkan CAR berpengaruh positif tidak signifikan terhadap kinerja keuangan (ROA). Hasil penelitian ini sesuai pendapat Muzzaki (2014), Sabir (2012) yang menyatakan tidak signifikannya CAR terhadap ROA dikarenakan bank yang mempunyai modal besar namun tidak dapat menggunakan modalnya secara efektif untuk menghasilkan laba.

Variabel GCG bernilai positif pada $t_{\text {hitung }} 0,425615$ dengan nilai signifikasi 0,7912. Karena nilai signifikasi $07912>0,05$ dan memiliki koefisien bernilai positif yaitu 0,006125, maka dapat disimpulkan bahwa hipotesis pertama (H5) ditolak artinya GCG berpengaruh positif tidak signifikan terhadap kinerja keuangan (ROA) bank umum syariah di Indonesia periode 2013-2017.

Berdasarkan nilai $t_{\text {hitung }}$ sebesar 0,268660 dan nilai itu lebih kecil daripada nilai $t_{\text {table }}$ sebesar 1,68967, sehingga dapat disimpulkan GCG berpengaruh positif tidak signifikan terhadap kinerja keuangan (ROA). Hasil penelitian ini sesuai pendapat Nida (2015) yang menyatakan kehadiran Good Corporate Governance dalam perusahaan bertujuan untuk meningkatkan kinerja perusahaan melalui supervisi atau monitoring kinerja manajemen berdasarkan kerangka peraturan nyatanya belum maksimal dilakukan oleh Bank Umum Syariah. Hasilnya menunjukkan bahwa Good Corporate Governance dari bank syariah di Indonesia telah mematuhi peraturan dari Bank Indonesia. Namun, beberapa bank belum dinilai sesuai dengan kenyataan. Jadi, ada ketidakcocokan anatara skor penilaian diri dengan praktek. Ditunjukkan juga bahwa praktik Good Corporate Governance dari 
bank syariah di Indonesia tidak mampu meningkatkan kinerja keuangan (ROA).

Hasil penelitian ini menunjukkan bahwa Bank Umum Syariah belum mampu mengelola perusahaan secara professional, modern dan sesuai dengan tujuan-tujuan syariah. Hal tersebut mendukung penelitian sebelumnya yang dilakukan oleh Wicaksono (2014), Ekaputri (2014), Nurbaidah (2017) yang menyatakan bahwa Good Corporate Governance tidak berpengaruh signifikan terhadap kinerja keuangan (ROA).

\section{SIMPULAN}

Berdasarkan hasil penelitian dan pembahasan penelitian yang telah dilakukan oleh peneliti, maka kesimpulan dari penelitian ini adalah sebagai berikut :

1. Secara simultan variabel NPF, FDR, BOPO,CAR, dan GCG berpengaruh signifikan terhadap kinerja keuangan (ROA) bank umum syariah di Indonesia periode 2013-2017. Berdasarkan besarnya adjusted $\mathrm{R}^{2}$ adalah 0,699 yang artinya 69,9\% kinerja keuangan (ROA) bank umum syariah dipengaruhi oleh variabel independen, sedangkan 30,1\% dipengaruhi oleh faktor lain diluar penelitian.

2. Secara parsial NPF berpengaruh positif tidak signifikan terhadap kinerja keuangan (ROA) bank umum syariah di Indonesia periode 2013-2017.

3. Secara parsial FDR berpengaruh positif tidak signifikan terhadap kinerja keuangan (ROA) bank umum syariah di Indonesia periode 2013-2017.

4. Secara parsial BOPO berpengaruh negatif signifikan terhadap kinerja keuangan (ROA) bank umum syariah di Indonesia periode 2013-2017.

5. Secara parsial GCG berpengaruh positif tidak signifikan terhadap kinerja keuangan (ROA) bank umum syariah di Indonesia periode 2013-2017. 


\section{DAFTAR PUSTAKA}

Adiono, Cahyo Lutfi dan Mahfud Sholihin. 2014. Analisis Pengungkapan Tata Kelola Bank Syariah di Indonesia. Jurnal Keuangan dan Perbanka, Vol., 58 No., 02, hal. 268-277.

Adyani, Lyla Rahma dan Djoko Sampurno. 2012. Analisis Faktor-Faktor yang Mempengaruhi Profitabilitas (ROA) pada Bank Umum Syariah Periode 2005-2010. Jurnal Ekonomi Manajeme, Universitas Diponegoro Semarang.

Andriani dan Silviana Agustami. 2016. Pengaruh Good Corporate Governance dan Ukuran Perusahaan terhadap Kinerja Keuangan Perusahaan (Pada Perusahaan Perbankan yang Terdaftar di Bursa Efek Indonesia (BEI) Tahun 2010-2014). Jurnal Riset Akuntansi dan Keuangan, Vol., 4 No., 2.

Arifin, Zainal. 2005. Teori Keuangan dan Pasar Modal. Yogyakarta : Ekonosia. . 2009. Dasar-Dasar Manajemen Bank Syariah. Jakarta: Azkia Publisher

Armereo, Crystha. 2015. Analisis Faktor - Faktor yang Mempengaruhi Profitabilitas Bank Syariah yang Terdaftar di Bursa Efek Indonesia Indonesia. Jurnal Ilmiah Ekonomi Global Masa Kini, volume 06 No.01.

Astohar. 2016. Pengaruh Capital Adequacy Ratio (CAR) dan Financing To Deposit Ratio Terhadap Profitabilitas Perbankan Syariah di Indonesia dengan Inflasi sebagai Variabel Pemoderasi. Among Makarti, Vol. 9 No.8.

Azwar, Saifuddin. 2014. Metode Penelitian. Yogyakarta: Pustaka Pelajar.

Dendawijaya, Lukman. 2009. Manajemen Perbankan. Jakarta: Ghalia Indonesia.

Ekaputri, Cahaya. 2014. Tata Kelola, Kinerja Rentabilitas, dan Risiko Pembiayaan Perbankan Syariah. Journal of Business and Banking, Volume 4, No.1, 91-10.

Hakim, Ningsukma dan Haqiqi Rafsanjani. 2016. Pengaruh Internal Capital Adequensy Ratio (CAR), Financing To Deposit Ratio (FDR) dan Biaya Operasional Per Pendapatan Operasional (BOPO) dalam Peningkatan Profitabilitas Industri Bank Syariah di Indonesi, Jurnal Aplikasi 
Manajemen Sekolah Pasca Sarjana Universitas Airlangga Surabaya, Vol. 14 No. 1.

Hasibuan, M. 2008. Dasar-dasar perbankan. Jakarta: Bumi Aksara.

Kurniasih, Erni. 2012. Pengaruh Capital Adequacy Ratio (CAR), Non Performing Financing (NPF), Financing To Deposit Ratio (FDR), Biaya Operasional Pendapatan Operasional (BOPO), Suku Bunga dan Inflasi terhadap Profitabilitas (Perbandingan Bank Umum Syariah dan Bank Umum Konvensional periode 2007-2011). Skripsi. Yogyakarta.

Layaman dan Qoonitah Fitri Al-Nisa. 2016. Analisis Pengaruh Capital Adequacy Ratio (CAR) dan Financing to Deposit Ratio (FDR) terhadap Profitabilitas Bank Syariah. Al Anwal, Vol. 8, No. 4.

Lemiyana dan Erdah Litriani. 2016. Pengaruh NPF, FDR, OPO terhadap Return On Assset (ROA) pada Bank Umum Syariah. I-Economic, Vol. 2. No.1.

Muhammad. 2005. Manajemen Bank Syariah. Yogyakarta: UPP STIM YKPN.

Mukti, Nur Abidah. 2016. Pengaruh BOPO dan FDR Terhadap Profitabilitas BPR Syariah Dengan Risiko Pembiayaan Sebagai Variabel Intervening (Studi Empiris Pada Bank PembiayaanRakyat Syariah Provinsi DKI Jakarta, Jawa Barat dan Banten yang Terdaftar di Bank Indonesia Periode 20122015). Skripsi. Akuntansi Fakultas Ekonomi dan Bisnis Universitas Jember.

Muliawati, Sri dan Khoirrudin. 2015. Faktor-Faktor Penentu Profitabilitas Bank Syariah di Indonesia. Management Analysis Journal Universitas Negeri Semarang, Vol 4, no.1.

Niode, Nenda Nurjanah. 2016. Pengaruh CAR, Pembiayaan, NPF, Dan BOPO Terhadap ROA Bank Umum Syariah Di Indonesiaperiode 2010-2015. Skripsi. Fakultas Ekonomi Universitas Diponegoro Semarang.

Nurbaidah, Siti. 2017. Pengaruh Capital Adequacy Ratio, Financing to Deposit Ratio, Non Performing Ratio, Biaya Operasional Pendapatan Operasional, dan Good Corporate Governance terhadap Profitabilitas yang Terdaftar di Bank Indonesia. Thesis. Fakultas Ekonomi Universitas Negeri Medan.

Pramudhito R.A. Sasongko.2014. Analisis Pengaruh CAR, NPF, BOPO, FDR, dan NCOM terhadap Profitabilitas Bank Umum Syariah di Indonesia. Skripsi. Fakultas Ekonomika dan Bisnis Jurusan Manajemen. 
Prasojo. 2015. Pengaruh Penerapan Good Corporate Governance terhadap Kinerja Keuangan Bank Syariah. Jurnal Dinamika Akuntansi dan Bisnis, Vol.2, No. 1.

Rahmat, Muhammad. 2012. Pengaruh CAR, FDR, dan NPF terhadap Profitabilitas pada Bank Syariah. Skripsi. Fakultas Ekonomi dan Bisnis Universitas Hasanuddin Makassar.

Ramadhan, Faniditya. 2015. Pengaruh Capital Adequacy Ratio (CAR), Financing to Deposit Ratio (FDR), dan Non Performing Financing (NPF) terhadap Profitabilitas PT Bank Mega Syariah. Skripsi. Fakultas Syariah dan Hukum UIN Syarif Hidayatullah Jakarta.

Ramantha, I Wayan dan A.A. Yogi Prasanjaya. 2013. Analisis Pengaruh Rasio CAR, BOPO, LDR dan Ukuran Perusahaan terhadap Profitabiitas Bank yang Terdaftar di BEI. E-Jurnal Akuntansi Universitas Udayana, Vol. 4, No. 1.

Rendiana, Gery. 2015. Analisis Pengaruh Efisiensi BOPO dan CAR Terhadap ROA pada Perbankan Syariah yang Terdaftar di OJK Tahun 2010-2014. Skripsi. Universitas Islam Bandung.

Riyadi, Selamet. 2006. Banking Assets and Liability Management Edisi 3. Jakarta: Lembaga Penerbit Fakultas Ekonomi Universitas Indonesia.

Riyanto, Bambang. 2003. Dasar-Dasar Pembelanjaan Perusahaan Edisi 4. Yogyakarta : Yayasan Penerbit FE UGM.

Sejati, Hidayat Suryo. 2016. Pengaruh FDR, Suku Bunga, CAR, BOPO, NPF, NPM, Likuiditas Terhadap Profitabilitas Bank Umum Syariah Periode 2010-2013. Skripsi. Fakultas Syari'ah dan Hukum Universitas Islam Negeri Sunan Kalijaga Yogyakarta.

Sholihah, Nikmatus dan Jaka Sriyana. 2015. Profitabilitas Bank Syariah pada Kondisi Operasional Tinggi. Prosiding Semnas, Penelitian Ekonomi dan Bisnis Keuangan,Ilmu Ekonomi UII Yogyakarta.

Sudarwantoro, Yusuf. 2009. Analisis Pengaruh Pertumbuhan Dana Pihak Ketiga, Capital Adequacy Ratio, Net Interest Margin, dan Non Performing Loan terhadap Return On Assets pada bank yang terdaftar di Bursa Efek Indonesia Tahun 2007-2012. Jurnal MBTI Telkom University.

Suryani. 2011. Analisis Pengaruh Fianancing to Deposit Ratio (FDR) terhadap Profitabilitas Perbankan Syariah di Indonesia. Walisongo, Volume19, No. 1. 
Rima Cahya Suwarno dan Ahmad Mifdhol Muthohar

Theresia, Debby. 2013. Pengaruh NPL, LDR, CAR, NIM, dan GCG terhadap ROA (Studi pada Bank yang terdaftar di BEI periode 2004-2012). Skripsi. Fakultas Ekonomika dan Bisnis Semarang.

Wahyuni, Sri. 2016. Pengaruh CAR, NPF, dan BOPO terhadap Profitabilitas Bank Umum Syariah (Periode 2011-2015). Skripsi. Fakultas Syariah dan Hukum uin Syarif Hidayatullah Jakarta.

Wibowo, E.S dan Muhammad Syaichu. 2013. Analisis Pengaruh Suku Bunga, Inflasi, CAR, BOPO, NPF Terhadap Profitabilitas Bank Syariah. Diponegoro Journal Of Management, Vol. 2 No. 2.

Wicaksono, Tangguh. 2014. Pengaruh Good Corporate Governance terhadap Profitabilitas Perusahaan (Studi Empiris pada Perusahaan Peserta Corporate Governance Perception Index (CGPI) tahun 2012). Skripsi. Fakultas Ekonomi dan Bisnis Universitas Diponegoro.

Yusuf, Muhammad. 2017. Dampak Indikator Rasio Keuangan terhadap Profitabilitas Bank Umum Syariah di Indonesia. Jurnal Keuangan dan Perbankan, Vol. 13 No. 2.

www.ojk.go.id 